\title{
GERAKAN LITERASI SEKOLAH DENGAN MODEL MLM DALAM MENINGKATKAN MINAT BACA SISWA
}

\author{
Irwan Hermansah $^{1}$, Ari Kartini' \\ ihermawan23@gmail.com ${ }^{1}$ arikartini00@gmail.com² \\ SDN Cileungsir kec. Cipatujah Kab. Tasik ${ }^{1}$, Pendidikan Bahasa dan Sastra Indonesia \\ Fakultas Ilmu Sosial, Bahasa dan Sastra Institut Pendidikan Indonesia (IPI) Garut ${ }^{2}$
}

\begin{abstract}
Abstrak: Kurangnya minat siswa terhadap membaca akan menghambat tingkat perkembangan intelektual siswa dalam mendapatkan informasi dan ilmu pengetahuan. Penelitian ini mendeskripsikan pengembangan gerakan literasi dengam model membaca lima belas menit (MLM) untuk meningkatkan minat baca siswa sekolah dasar. Penelitian ini merupakan penelitian kualitatif dengan metode deskriftif kuantitatif. Subjek dalam penelitian adalah seluruh siswa kelas 5 sekolah dasar di SDN Cileungsir kec. Cipatujah kab. Tasik. Hasil penelitian diperoleh temuan sebagai berikut 1) Model MLM untuk mengembangkan minat baca siswa kelas 5 dilaksanakan dengan pola pembiasaan, teknik yang beragam dan beragam jenis bacaan; 2) hasil penilaian angket terhadap minat baca menunjukan adanya peningkatan minat baca siswa kelas 5 SDN Cilengsir; 3) Ketertarikan siswa kelas 5 SDN Cilengsir terhadap buku yang dibaca setelah dilakukan kegiatan MLM masih didominasi oleh minatnya siswa terhadap buku yang sifatnya hiburan dibandingkan dengan buku mata pelajaran.
\end{abstract}

Kata kunci: Gerakan Literasi Sekolah, Membaca Lima Belas Menit, Minat Baca

\section{SCHOOL LITERACY MOVEMENT WITH MLM MODELS IN INCREASING STUDENT READ INTEREST}

\begin{abstract}
The lack of student interest in reading will impede the level of students ' intellectual development in obtaining information and science. This study describes the development of literacy movements with the fifteen-minute reading model (MLM) to increase interest in elementary school students. This research is a qualitative study with quantitative deskriftive methods. The subject in the study is all grade 5 students elementary School at SDN Cileungsir Kec. Tasik. Results obtained findings as follows 1) MLM models to develop interest in grade 5 students are carried out with habituation patterns, diverse techniques and various types of readings; 2) The results of a poll assessment of the interest reading showed an increased interest in the reading of Grade 5 students at SDN Cilengsir; 3) The interest of Grade 5 students of SDN Cilengsir to the books that read after the MLM activities are still dominated by the students ' interest in the book that is a nature of entertainment compared to the textbook.
\end{abstract}

Keywords: School literacy Movement, fifteen minute reading, read interest. PENDAHULUAN 
Irwa, Ari. Gerakan Literasi Sekolah Dengan...

Pepatah mengatakan membaca merupakan jendela dunia, di mana semua informasi yang ingin diketahui mudah ditemukan dengan kegiatan membaca. Literasi merupakan jalan satu-satunya untuk mendapatkan pemahaman utuh tentang sebuah realitas. Membudayakan literasi bisa menjadi modal dasar untuk menganalisis dan mengkritik dari berbagai fenomena yang terjadi. Akan tetapi, saat ini kegiatan literasi kurang diminati oleh sebagian banyak orang(Nopilda \& Kristiawan, 2018).

Permasalahan literasi bukan hanya berkaitan dengan penguasaan keterampilannya saja. Akan tetapi indikator lain yang menjadi masalah dalam literasi adalah kurangnya minat untuk melakukan aktivitas membaca. Salah satu permasalahan yang terjadi di SDN Cileungsir kab. Tasikmalaya, di mana banyak, siswa jika disuguhkan buku untuk dibaca mereka terlihat kurang tertarik dan lebih memilih bermain di lapangan sekolah. Selain itu, saat ditawari buku untuk dibaca di rumah, mereka lebih senang bermain gawai. Fenomena ini sungguh miris jika dibiarkan begitu saja. Aktivitas membaca harus dibiasakan sejak dini, sehingga kemampuan daya nalar siswa akan mudah meningkat.

Tahun 2015 kementerian pendidikan memberi perhatian penuh terhadap dua riset internasional yaitu PIRLS dan PISA. Hal itu terjadi karena Indonesia mendapat prestasi yang rendah dalam hal kemampuan membaca siswa kelas VI Sekolah Dasar. Tahun 2011 PIRLS menyimpulkan bahwa Indonesia berada pada urutan ke 45 dari 48 negara yang diriset (IEA, 2012). Sedangkan, riset PISA tahun 2009, 2012, dan 2015 menunjukkan urutan Indonesia masing- masing pada 57 dari 63 negara, 64 dari 65 negara, dan 64 dari 72 negara (OECD, 2016). Berdasarkan hasil riset berkaitan dengan prestasi yang rendah tersebut maka kemendikbud menerbitkan Peraturan Menteri nomor 23 tahun 2015 tentang penumbuhan budi pekerti yang di dalamnya tersurat mengenai pembiasaan budaya literasi. Melalui Permendikbud inilah digagas Gerakan Literasi Sekolah (GLS) untuk menciptakan warga yang literat di lingkungan sekolah (Hidayat et al., 2018).

Sebagai wujud untuk membantu pemerintah, program Gerakan Literasi Sekolah ini telah diterapkan dan dikembangkan di sekolah-sekolah khusunya sekolah dasar dengan melakukan penelitian. (Faradina, 2017) melaksanakan penelitian dengan tujuan untuk mengetahui pengaruh Program Gerakan Literasi Sekolah terhadap Minat Baca Siswa. Selain itu, (Hidayat et al., 2018) melaksanakan penelitian dengan tujuan 
Irwa, Ari. Gerakan Literasi Sekolah Dengan...

mendeskripsikan mengenai pelaksanaan Gerakan Literasi Sekolah (GLS) di sekolah dasar.

Aspek kebaharuan untuk penelitian yang akan dilakukan berkenaan dengan program Gerakan Literasi Sekolah (GLS) ini; pertama penelitian ini akan mendeskripsikan pola penerapan program GLS di sekolah dasar yang masih belum mempunyai fasilitas lengkap; kedua berkaitan dengan peningkatan minat baca siswa setelah implemantasi GLS dilaksanakan; dan ketiga mendeskripsikan buku apa saja yang disukai siswa untuk dibaca dalam kegiatan ini.

\section{Peningkatan Minat baca}

Menumbuhkan minat pada diri siswa harus dilakukan dari berbagai faktor. Salah satu komponen penting dari motivasi belajar adalah minat, yang memainkan peran dalam pengembangan pengenalan kata pada tingkat pemula (Kikas et al., 2016). Minat baca dan konsep diri pembaca sangat penting untuk pembelajaran siswa dan harus dipelajari secara ekstensif sebagai kekuatan pendorong dalam pengembangan membaca permulaan (Walgermo et al., 2018). Sinambela (2005) memaparkan minat membaca adalah sikap positif dan adanya rasa keterikatan dalam diri anak terhadap aktivitas membaca dan tertarik terhadap buku bacaan. Pengukuran peningkatan minat baca dilakukan menggunakan kuesioner yang dikembangkan berdasarkan Skala Nilai-Tugas Finlandia untuk anak-anak dan pendekatan teoritis yang dijelaskan oleh Eccles (2005). Indikator utama pengukuran terdiri dari tiga item (Membaca itu menyenangkan; saya suka membaca di sekolah; saya suka membaca di rumah (Kikas et al., 2016).

\section{Pengembangan GLS dengan Pola MLM}

Gerakan Literasi Sekolah adalah suatu usaha atau kegiatan yang bersifat partisipatif dengan melibatkan warga sekolah (mulai dari peserta didik, guru, kepala sekolah, tenaga kependidikan, pengawas sekolah, komite sekolah, orang tua/wali murid peserta didik), akademisi, penerbit, media massa, masyarakat (tokoh masyarakat yang biisa merepresentasikan keteladanan, dunia usaha, dan lain sebagainya), dan pemangku kepentingan di bawah koordinasi Direktorat Jenderal Pendidikan Dasar dan Menengah Kementerian Pendidikan dan Kebudayaan. 
Irwa, Ari. Gerakan Literasi Sekolah Dengan...

Pola pelaksanaan gerakan literasi sekolah pada dasarnya mengacu pada prinsip

GLS yang ditetapkan dalam Peraturan Menteri Pendidikan dan Kebudayaan Republik Indonesia Nomor 23 Tahun 2015 tentang Penumbuhan Budi Pekerti, 2015. Prinsip Gerakan Literasi Sekolah dilakukan dalam tiga tahapan yaitu, pembiasaan, pengembangan, dan pembelajaran.

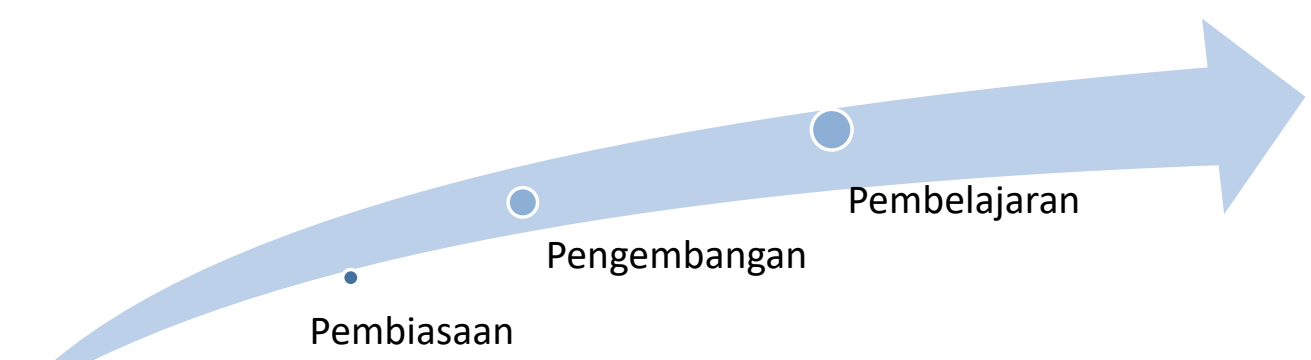

Bagan 1. Tahapan Pelaksanaan Gerakan Literasi Sekolah

Berdasarkan acuan prinsip GLS, pola yang dilakukan dalam penelitian ini hanya fokus pada tahapan pembiasaan, sehingga bentuk pola pelaksanaan GLS dikemas dalam kegiatan membaca lima belas menit (MLM) sebelum pembelajaran dimulai.

Tabel 1: Pengembangan Gerakan Literasi Sekolah melalui Kegiatan MLM

\begin{tabular}{|c|c|}
\hline Prinsip Kegiatan MLM & Variasi Kegiatan MLM \\
\hline Menyenangkan & Membacakan nyaring (read aloud) \\
\hline Bervariasi & Membaca mandiri atau membaca dalam hati \\
\hline Rutin & Membaca bersama \\
\hline Berimbang & Mendongengkan cerita rakyat \\
\hline
\end{tabular}

Adapun teknik pelaksanaan pengembangan GLS dengan pola MLM adalah

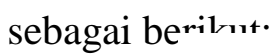

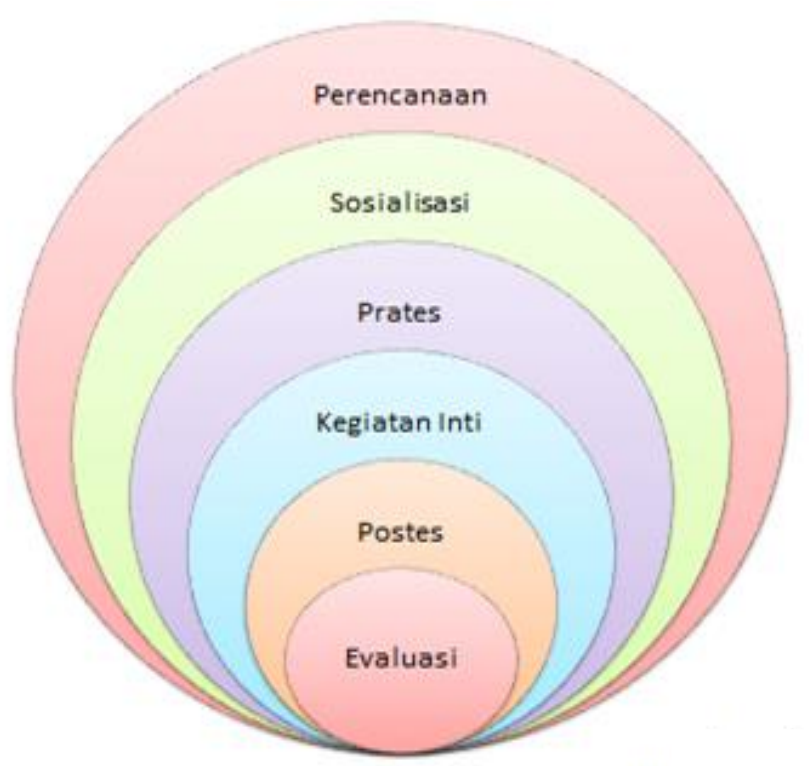

Bagan 2. pelaksanaan pengembangan GLS dengan pola MLM 
Irwa, Ari. Gerakan Literasi Sekolah Dengan...

\section{METODOLOGI PENELITIAN}

\section{Metode Penelitian}

Penelitian ini termasuk ke dalam penelitian kualitatif dengan metode deskriftif kuantitatif. Pengumpulan data menggunakan teknik angket yang dikelola secara kuantitatif untuk mengetahui perkembangan minat baca siswa setelah dilaksanakan GLS. Sedangkan, metode analisis data yang digunakan adalah model Miles dan Huberman dimulai dari reduksi data, deskripsi data, dan penarikan kesimpulan (Miles, Mattew B. \& Huberman, 2007). Sampel dalam penelitian ini adalah siswa kelas 5 sekolah dasar SDN Cileungsir kab. Tasikmalaya, sebanyak 11 siswa. Subjek penelitian dibatasi hanya khusus kelas lima saja agar mudah untuk dikondisikan dan sebagai uji coba awal untuk mengetahui keberhasilan pengembagan program GLS ini. Jika ada peningkatan positif terhadap minat baca siswa kelas lima, tentu saja akan diterapkan untuk siswa kelas lainnya.

\section{HASIL}

Proses pelaksanaan Gerakan Literasi Sekolah dengan pola Membaca Lima Belas Menit ini dilakukan sebelum pembelajaran inti dimulai. Di bawah ini bentuk pola kegiatan MLM;

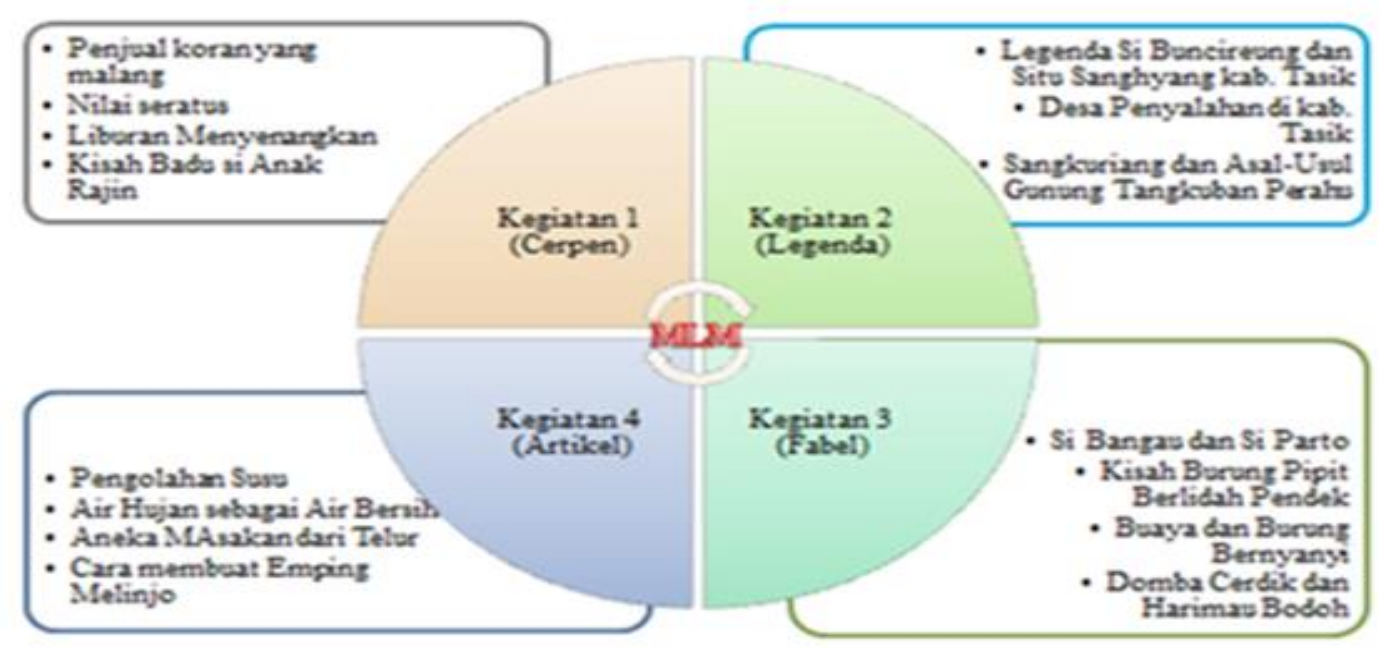

Bagan 3. Proses Inti Kegiatan MLM 
Irwa, Ari. Gerakan Literasi Sekolah Dengan...

Kegiatan aktualisasi untuk mengembangkan minat baca siswa kelas 5 dengan

kegiatan MLM dilaksanakan dengan pola pembiasaan, beragam teknik dan beragam jenis bacaan. Di bawah ini hasil kegiatan aktualisasi yang dilaksanakan.

Tabel 2. Aplikasi Kegiatan Membaca Lima Belas Menit (MLM)

\begin{tabular}{|c|c|}
\hline KEGIATAN & RINCIAN KEGIATAN \\
\hline Preetes & $\begin{array}{l}\text { - Siswa mengisi angket dengan indikator tentang minat baca siswa kelas } 5 \\
\text { sebelum dilaksanakan kegian MLM }\end{array}$ \\
\hline $\begin{array}{l}\text { MLM } 1 \\
\text { CERPEN }\end{array}$ & $\begin{array}{l}\text { - Siswa membaca cerpen selama } 15 \text { menit sebelum pembelajaran di mulai. } \\
\text { - Kegiatan MLM dilaksanakan di luar dan dalam kelas sesuai situasi dan } \\
\text { kondisi yang nyaman. } \\
\text { kegiatan membaca cerpen dilaksanakan selama } 4 \text { hari dengan judul yang } \\
\text { berbeda. judul cerpen yang dibaca siswa, yaitu: Penjual Koran yang Malang, } \\
\text { Nilai Seratus, Liburan yang Meneyenangkan, Kisah Badu si Anak Rajin }\end{array}$ \\
\hline $\begin{array}{c}\text { MLM } 2 \\
\text { LEGENDA }\end{array}$ & $\begin{array}{l}\text { - Siswa membaca legenda selama } 15 \text { menit sebelum pembelajaran di mulai } \\
\text { - Kegiatan MLM dilaksanakan di luar dan dalam kelas sesuai situasi dan } \\
\text { kondisi yang nyaman. } \\
\text { kegiatan membaca legenda dilaksanakan selama } 3 \text { hari dengan judul yang } \\
\text { berbeda. Judul legenda yang dibaca siswa, yaitu: Si Buncireung dan Situ } \\
\text { Sanghyang kab. Tasik, Desa Penyalahan di kab. Tasik, Sangkuriang dan } \\
\text { Gunung Tangkuban Perahu. }\end{array}$ \\
\hline $\begin{array}{l}\text { MLM } 3 \\
\text { FABEL }\end{array}$ & $\begin{array}{l}\text { - Siswa membaca fabel selama } 15 \text { menit sebelum pembelajaran di mulai. } \\
\text { - Kegiatan MLM dilaksanakan di luar dan dalam kelas sesuai situasi dan } \\
\text { kondisi yang nyaman. } \\
\text { kegiatan membaca fabel dilaksanakan selama } 4 \text { hari dengan judul yang } \\
\text { berbeda. judul fabel yang dibaca siswa, yaitu: Si Bangau dan Si Parto; Kisah } \\
\text { Burung Pipit Berlidah Pendek; Buaya dan Burung Bernyanyi; Domba Cerdik } \\
\text { dan Harimau Bodoh. }\end{array}$ \\
\hline $\begin{array}{c}\text { MLM } 4 \\
\text { ARTIKEL }\end{array}$ & $\begin{array}{l}\text { - Siswa membaca artikel selama } 15 \text { menit sebelum pembelajaran di mulai. } \\
\text { - Kegiatan MLM dilaksanakan di luar dan dalam kelas sesuai situasi dan } \\
\text { kondisi yang nyaman. } \\
\text { kegiatan membaca artikel dilaksanakan selama } 4 \text { hari dengan judul yang } \\
\text { berbeda. judul artikel yang dibaca siswa, yaitu: Pengolahan Susu; Air Hujan } \\
\text { sebagai Air Bersih; Aneka Masakan dari Telur; Cara membuat Emping } \\
\text { Melinjo. }\end{array}$ \\
\hline $\begin{array}{l}\text { MLM } 5 \\
\text { BEBAS }\end{array}$ & $\begin{array}{l}\text { - Siswa membaca cerpen selama } 15 \text { menit sebelum pembelajaran di mulai. } \\
\text { - Kegiatan MLM dilaksanakan di luar dan dalam kelas sesuai situasi dan } \\
\text { kondisi yang nyaman. } \\
\text { - } \\
\text { kegiatan membaca cerpen dilaksanakan selama } 4 \text { hari dengan judul yang } \\
\text { berbeda dan peminatan jenis bacaan yang berbeda sesuai dengan minat siswa. }\end{array}$ \\
\hline Postes & $\begin{array}{l}\text { - Siswa mengisi angket dengan indikator tentang minat baca siswa kelas } 5 \\
\text { setelah dilaksanakan kegian MLM. } \\
\text { - Siswa mengisi angket dengan indikator tentang kepuasan pelaksanaan } \\
\text { kegiatan MLM. }\end{array}$ \\
\hline
\end{tabular}


Irwa, Ari. Gerakan Literasi Sekolah Dengan...

Peningkatan minat baca siswa kelas 5 dengan melakukan kegiatan Membaca

Lima Belas Menit (MLM) dilakukan dengan mengisian angket oleh siswa kelas 5.

Adapaun hasil angket yang diperoleh adalah sebagai berikut;

Tabel 3. Persentase Hasil Angket Minat Baca Siswa Kelas 5 SDN Cileungsir Cipatujah Tasikmalaya sebelum dilaksakanan Kegiatan MLM

\begin{tabular}{|c|c|c|c|}
\hline Pernyataan Angket & Ya & Mungkin & Tidak \\
\hline 1. Saya termasuk orang yang suka membaca & 2 & 11 & 1 \\
\hline 2. $\quad$ Setiap hari saya suka membaca buku & 2 & 6 & 6 \\
\hline 3. Saya suka membaca buku ketika istirahat & 0 & 0 & 14 \\
\hline 4. Saya selalu menggunakan waktu luang untuk membaca buku & 3 & 3 & 8 \\
\hline 5. Saya selalu membaca buku saat di rumah & 6 & 5 & 3 \\
\hline Persentase Pernyataan $(+)$ & $\begin{array}{r}13 \\
18,57 \%\end{array}$ & $\begin{array}{r}25 \\
35,71\end{array}$ & $\begin{array}{r}32 \\
45,72 \%\end{array}$ \\
\hline 6. Saya menyukai buku hiburan dibandingkan buku pelajaran & 7 & 2 & 5 \\
\hline Persentase Pernyataan Imbang & $\begin{array}{r}7 \\
50 \%\end{array}$ & $\begin{array}{r}2 \\
14,29\end{array}$ & $\begin{array}{r}5 \\
35,71\end{array}$ \\
\hline 7. Saya jarang sekali membaca buku & 5 & 2 & 7 \\
\hline 8. Saya tidak pernah membaca buku & 4 & 8 & 2 \\
\hline 9. Saya lebih suka bermain dibandingkan membaca buku & 5 & 5 & 4 \\
\hline 10. Saya membaca buku apabila diberi tugas oleh guru & 12 & 1 & 1 \\
\hline Persentase Pernyataan (-) & $\begin{array}{r}26 \\
46,42 \%\end{array}$ & $\begin{array}{r}16 \\
28,58 \%\end{array}$ & $\begin{array}{r}14 \\
25 \%\end{array}$ \\
\hline
\end{tabular}

Sumber: Eccles (2005) dan (Kikas et al., 2016)

Tabel 4. Persentase Hasil Angket Minat Baca Siswa Kelas 5 SDN Cileungsir Cipatujah Garut sesudah dilaksanakan Kegiatan MLM

\begin{tabular}{|c|c|c|c|}
\hline Pernyataan Angket & $\mathbf{Y a}$ & Mungkin & Tidak \\
\hline 1. Saya termasuk orang yang suka membaca & 4 & 10 & 0 \\
\hline 2. $\quad$ Setiap hari saya suka membaca buku & 5 & 7 & 2 \\
\hline 3. Saya suka membaca buku ketika istirahat & 4 & 0 & 10 \\
\hline $\begin{array}{l}\text { 4. Saya selalu menggunakan waktu luang untuk membaca } \\
\text { buku }\end{array}$ & 5 & 6 & 3 \\
\hline $\begin{array}{ll}\text { 5. } & \text { Saya selalu membaca buku saat di rumah }\end{array}$ & 10 & 1 & 3 \\
\hline Persentase Pernyataan $(+)$ & $\begin{array}{r}28 \\
40 \%\end{array}$ & $\begin{array}{r}24 \\
34,28 \%\end{array}$ & $\begin{array}{r}18 \\
25,72 \%\end{array}$ \\
\hline 6. Saya menyukai buku hiburan dibandingkan buku pelajaran & 6 & 4 & 4 \\
\hline Persentase Pernyataan Imbang & $\begin{array}{r}6 \\
42,86 \%\end{array}$ & $\begin{array}{r}4 \\
28,57 \%\end{array}$ & $\begin{array}{r}4 \\
28,57 \%\end{array}$ \\
\hline 7. Saya jarang sekali membaca buku & 5 & 0 & 9 \\
\hline 8. Saya tidak pernah membaca buku & 4 & 5 & 5 \\
\hline Saya lebih suka bermain dibandingkan membaca buku & 4 & 4 & 6 \\
\hline 10. Saya membaca buku apabila diberi tugas oleh guru & 8 & 2 & 4 \\
\hline Persentase Pernyataan (-) & $\begin{array}{r}21 \\
37,5 \%\end{array}$ & $\begin{array}{r}11 \\
19,64 \%\end{array}$ & $\begin{array}{r}24 \\
42,86 \%\end{array}$ \\
\hline
\end{tabular}

Sumber: Eccles (2005) dan (Kikas et al., 2016) 
Irwa, Ari. Gerakan Literasi Sekolah Dengan...

\section{PEMBAHASAN}

Peningkatan minat baca siswa kelas 5 dengan melakukan kegiatan aktualisasi Membaca Lima Belas Menit (MLM) dilakukan dengan pengisian angket oleh siswa kelas 5. Indikator pernyataan dalam angket terbagi atas 3 jenis, yaitu; pernyataan positif, imbang, dan negatif. Pernyataan positif merupakan kegiatan realitas yang dilakukan oleh siswa keterkaitan dengan keinginan siswa dalam membaca buku sebelum dilakukan kegiatan MLM. Pernyataan imbang berkaitan dengan bentuk pernyataan yang hanya menunjukan minat siswa dalam memilih bahan bacaan. Sedangkan, pernyataan negatif adalah pernyataan mengenai keinginan siswa dalam membaca buku.

Indikator pernyataan angket berkenaan dnegan psikologi dan kegiatan membaca yang dilakukan. Seperti yang dipaparkan Kikas (2016) Indikator utama pengukuran minat membaca terdiri dari tiga item (Membaca itu menyenangkan; saya suka membaca di sekolah; saya suka membaca di rumah).

Berdasarkan data tabel 3 di atas dapat di deskripsikan, bahwa minat siswa SDN Cileungsir kecamatan Cipatujah kabupaten Tasikmalaya, masih dikategorikan tergolong rendah. Hal ini dapat dilihat dai persentase indikator angket yang di isi oleh siswa. Angket pernyataan positif dengan perolehan persentase, yaitu 18,57\% menjawab Ya, $35,71 \%$ menjawab mungkin, dan 45,72 menjawab Tidak. Artinya, kegiatan membaca buku masih belum dilakukan oleh siswa kelas 5 SDN Cileungsir secara rutin, sesuai minat, serta keinginan. Ini dibuktikan jawaban Ya lebih rendah dibandingkan siswa yang menjawab Tidak. Hal ini sejalan dengan hasil penelitian yang diutarakan Triatna (2016) Para siswa lebih memilih di kelas, bercerita dengan teman, dibandingkan dengan membaca buku ke perpustakaan. Rendahnya minat baca siswa disebabkan siswa kurang memiliki perasaan, perhatian terhadap buku dan manfaat membaca, serta motivasi dari diri sendiri maupun dari orang lain (lingkungan).

Hasil kesimpulan awal mengenai rendahnya minat siswa kelas 5 SDN Cileungsir, juga diperkuat dengan hasil persentase angket pernyataan negatif yang dijawab oleh siswa. Hasil perhitungan menunjukkan, 46,42\% menjawab Ya, 28,58\% menjawab mungkin, dan $25 \%$ menjawab Tidak. Karena persentase siswa yang menjawab Ya lebih banyak dari pada siswa yang menjawab tidak, maka dapat dikatakan siswa kelas 5 SDN Cilengsir masih tergolong rendah minat bacanya. Wahyuni (2009) 
Irwa, Ari. Gerakan Literasi Sekolah Dengan...

memaparkan penyebab rendahnya minat baca siswa adalah pengaruh lingkungan keluarga dan sekitarnya yang kurang mendukung kebiasaan membaca.

Berdasarkan data tabel 4 di atas dapat di deskripsikan, bahwa minat siswa SDN Cileungsir kecamatan Cipatujah kabupaten Tasikmalaya, dikategorikan adanya peningkatan minat baca setelah dilakukan kegiatan MLM. Hal ini dapat dilihat dari persentase indikator agket yang di isi oleh siswa. Angket pernyataan positif dengan perolehan persentase, yaitu $40 \%$ menjawab Ya, 34,28\% menjawab mungkin, dan 25,72\% menjawab Tidak. Artinya, kegiatan membaca buku sudah dilakukan oleh beberapa siswa kelas 5 SDN Cileungsir secara rutin, sesuai minat, serta keinginan. Ini dibuktikan jawaban Ya lebih tinggi dibandingkan siswa yang menjawab Tidak.

Hasil peningkatan minat baca siswa kelas 5 SDN Cileungsir, juga diperkuat dengan hasil persentase angket pernyataan negatif yang dijawab oleh siswa. Hasil perhitungan menunjukkan, 37,5\% menjawab Ya, 19,64\% menjawab mungkin, dan 42,86\% menjawab Tidak. Karena persentase siswa yang menjawab Ya lebih rendah dari pada siswa yang menjawab tidak, maka dapat dikatakan adanya peningkatan minat baca siswa kelas 5 SDN Cileungsir kec. Cipatujah kab. Tasikmalaya

Ketertarikan siswa kelas 5 SDN Cilengsir terhadap buku yang dibaca setelah dilakukan kegiatan MLM masih didominasi oleh minatnya siswa terhadap buku yang sifatnya hiburan dibandingkan dengan buku mata pelajaran. Hal ini dibutikan dengan persentase hasil angket yaitu, 42,86\% siswa menyukai buku hiburan dan 28,57\% menyukai buku pelajaran. Buku hiburan memang mempunyai daya tarik tinggi di kalangan siswa sekolah dasar. Selain isinya yang tidak membosankan, bentuk, monograf, dan tampilan buku menarik perhatian siswa. Berbeda dengan buku ilmiah yang notabene hanya mengulas materi dengan bahasa yang baku. $\mathrm{Hl}$ ini sejalan dengan hasil penelitian yang diuatarakan oleh Hardianto (2011) memaparkan bahwa buku-buku populer informasinya lebih baru (update), judul buku lebih menarik, isinya cendrung bervariatif, misal disertai dengan gambar, teks yang tidak monoton, bahkan ada yang dilengkapi dengan warna-warna yang menguatkan pesan. Selain itu, bentuk tulisan, bahasa yang digunakan, gambar, font huruf, isi yang tidak baku dapat menarik perhatian pembaca. 
Irwa, Ari. Gerakan Literasi Sekolah Dengan...

SIMPULAN

Teknik kegiatan MLM dilaksanakan melalui konsep pembiasaan dengan menggunakan teknik membaca yang bervariasi seperti membaca dalam hati, membaca nyaring, dan membaca bersama. Situasi dan kondisi yang berbeda, dan jenis bacaan yang berbeda, yaitu cerpen, legenda, fabel, dan artikel ilmiah. Setelah dilaksanakan kegiatan MLM, minat baca siswa kelas 5 SDN Cilengsir kecamatan Cipatujah kabupaten Garut, mengalami peningkatan. Bahan bacaan yang paling disukali oleh siswa adalah buku yang sifatnya hiburan dibandingkan dengan buku pelarajan atau tulisan-tulisan ilmiah.

Beberapa rekomendasi yang diajukan dari hasil penelitian ini, yaitu: 1) sekolah hendaknya melengkapi fasilitas seperti ruang perpustakaan yang dilengkapi dengan beranekaragam buku bacaan; 2) guru harus melakukan pembiasaan kepada siswa untuk melakukan kegiatan membaca sebelum pembelajaran dimulai; 3) siswa harus mempunyai target kegiatan membaca minimal 1 bacaan dalam sehari.

\section{DAFTAR PUSTAKA}

Abidin, Yunus, dkk. 2017. Pembelajaran Literasi. Jakarta: Bumi Aksara.

Faizah, Dewi Utama dkk. 2016. Panduan Gerakan Literasi Sekolah di SekolahDasar. Jakarta: Direktorat Pembinaan Sekolah Dasar, Direktorat Jenderal Pendidikan Dasar dan Menengah Kementrian Pendidikan dan Kebudayaan.

Faradina, N. 2017. Pengaruh Program Gerakan Literasi Sekolah Terhadap Minat Baca Siswa di SD Islam Terpadu Muhammadiyah An-Najah Jatinom Klaten. the Influence and Obstacles of School Literacy Movement Program on. Hanata Widya, 6(8), 60-69.

Fianto, Farinia dkk. 2018. Bunga Rampai GLS Praktik Baik Pembelajaran dan Penumbuhan Budaya Literasi. Jakarta: Direktorat Jenderal Pendidikan Dasar dan Menengah Kementrian Pendidikan dan Kebudayaan.

Hardianto, D. (2011). Studi tentang minat baca mahasiswa Fakultas Ilmu Pendidikan UNY. Majalah Ilmiah Pembelajaran, 7(1).

Hidayat, M. H., Basuki, I. A., \& Akbar, S. 2018. Gerakan Literasi Sekolah di Sekolah Dasar. Jurnal Pendidikan, Volume: 3(2017), 810-817. http://journal.um.ac.id/index.php/jptpp/

Miles, Mattew B. \& Huberman, A. M. 2007. Analisis Data Kualitatif, Buku Sumber tentang Metode-Metode Baru. Jakarta: Universitas Indonesia Press.

Peraturan Menteri Pendidikan dan Kebudayaan Republik Indonesia Nomor 23 Tahun 
Irwa, Ari. Gerakan Literasi Sekolah Dengan... 2015 tentang Penumbuhan Budi Pekerti, Pub. L. No. Nomor 23 Tahun 2015 Tentang, 1 (2015). https://drive.google.com/file/d/1EdTC5oI9YYDgcXuDxdZIDpxTox8bcZyq/view

Kikas, E., Silinskas, G., Jõgi, A. L., \& Soodla, P. 2016. Effects of teacher's individualized support on children's reading skills and interest in classrooms with different teaching styles. Learning and Individual Differences, 49, 270-277. https://doi.org/10.1016/j.lindif.2016.05.015

Nopilda, L., \& Kristiawan, M. 2018. Gerakan Literasi Sekolah Berbasis Pembelajaran Multiliterasi Sebuah Paradigma Pendidikan Abad Ke- 21. Jurnal Manajemen, Kepemimpinan, Dan Supervisi Pendidikan, 3(2), 216-231.

Sinambela, N.L. 2005. Hubungan Minat Membaca dengan Kreativitas pada Siswa-siswi Kelas II SMP Negeri 5 Yogyakarta. Yogyakarta: Fakultas Psikologi Universitas Gadjah Mada.

Triatma, I. N. 2016. Minat baca pada siswa kelas VI sekolah dasar negeri delegan 2 prambanan sleman Yogyakarta. E-Jurnal Skripsi Program Studi Teknologi Pendidikan, 5(6), 166-178.

Wahyuni, S. (2009). Menumbuhkembangkan minat baca menuju masyarakat literat. Diksi, 16(2).

Walgermo, B. R., Frijters, J. C., \& Solheim, O. J. 2018. Literacy interest and reader self-concept when formal reading instruction begins. Early Childhood Research Quarterly, 44, 90-100. https://doi.org/10.1016/j.ecresq.2018.03.002 